\title{
WTO'ing a Resolution to the China Subsidy Problem
}

Chad P. Brown

Peterson Institute for International Economics, cbown@piie.com

Jennifer A. Hillman

Georgetown University Law Center, jah95@georgetown.edu

This paper can be downloaded free of charge from:

https://scholarship.law.georgetown.edu/facpub/2206

https://ssrn.com/abstract=3473890

Peterson Institute for International Economics, Working Paper No. 19-17.

This open-access article is brought to you by the Georgetown Law Library. Posted with permission of the author. Follow this and additional works at: https://scholarship.law.georgetown.edu/facpub

Part of the International Trade Law Commons, and the Law and Politics Commons 


\title{
WORKING PAPER
}

\section{9-17 WTO'ing a Resolution to the China Subsidy Problem}

\author{
Chad P. Bown and Jennifer A. Hillman \\ October 2019
}

\begin{abstract}
The United States, European Union, and Japan have begun a trilateral process to confront the Chinese economic model, including its use of industrial subsidies and deployment of state-owned enterprises. This paper seeks to identify the main areas of tension and to assess the legal-economic challenges to constructing new rules to address the underlying conflict. It begins by providing a brief history of subsidy disciplines in the General Agreement on Tariffs and Trade (GATT) and the World Trade Organization (WTO) predating any concerns introduced by China. It then describes contemporary economic problems with China's approach to subsidies, their impact, and the apparent ineffectiveness of the WTO's Agreement on Subsidies and Countervailing Measures (ASCM) to address them. Finally, it calls for increased efforts to measure and pinpoint the source of the problems-in a manner analogous to how the Organization for Economic Cooperation and Development (OECD) took on agricultural subsidies in the 1980s — before providing a legal-economic assessment of proposals for reforms to notifications, evidence, remedies, enforcement, and the definition of a subsidy.
\end{abstract}

JEL Code: F13

Keywords: WTO, subsidy, state-owned enterprise, dispute settlement

Chad P. Bown is the Reginald Jones Senior Fellow at the Peterson Institute for International Economics and Jennifer A. Hillman is senior fellow for trade and international political economy at the Council on Foreign Relations.

Authors' Note: A revised version of this paper is forthcoming in the Journal of International Economic Law. For helpful discussions and suggestions on earlier versions, we thank Kym Anderson, Simon Evenett, Joe Glauber, Bernard Hoekman, Tianlei Huang, Soumaya Keynes, Andrew Lang, Nicholas Lardy, Robert Lawrence, Will Martin, Petros Mavroidis, Douglas Nelson, Luca Rubini, Jeffrey Schott, and Anne van Aaken. Thanks to Eva Zhang and Shelton Fitch for research assistance as well as Melina Kolb and William Melancon for assistance with graphics. All remaining errors are our own.

(c) Peterson Institute for International Economics. All rights reserved.

This publication has been subjected to a prepublication peer review intended to ensure analytical quality. The views expressed are those of the authors. This publication is part of the overall program of the

Peterson Institute for International Economics, as endorsed by its Board of Directors, but it does not necessarily reflect the views of individual members of the Board or of the Institute's staff or management.

The Peterson Institute for International Economics is a private nonpartisan, nonprofit institution for rigorous, intellectually open, and indepth study and discussion of international economic policy. Its purpose is to identify and analyze important issues to make globalization beneficial and sustainable for the people of the United States and the world, and then to develop and communicate practical new approaches for dealing with them. Its work is funded by a highly diverse group of philanthropic foundations, private corporations, and interested individuals, as well as income on its capital fund. About 35 percent of the Institute's resources in its latest fiscal year were provided by contributors from outside the United States. A list of all financial supporters is posted at https://piie.com/sites/default/files/supporters.pdf. 


\section{Introduction}

At the $11^{\text {th }}$ M inisterial Conference of the World Trade Organization (WTO) in December 2017, the United States, European Union, and Japan agreed to work together in an effort to confront the Chinese economic model, particularly its conflict with their preferred, historical approach to a market-oriented and rules-based multilateral trading system. ${ }^{1}$ Their discussions since have reportedly focused on two issues: industrial subsidies and state-owned enterprises (SOEs), and the forced transfer of technology.

This paper seeks to identify the main areas of tension and to assess the legal-economic challenges to constructing new rules that would address the first of these issues, subsidies. It begins with an assessment of four main concerns with the WTO: the narrow definition of what constitutes a subsidy, the high evidentiary burden in proving the existence of a subsidy, the failure of the notification process, and the ineffectiveness of remedies in disciplining subsidies.

The definitional concern of "a subsidy" centers on the constrained nature of the entity considered capable of providing the requisite financial contribution: only "a government or public body," with the Appellate Body narrowing the term "public body" to encompass only those entities that exercise governmental functions. This tight definition often means that SOES escape scrutiny. Similarly, other government policies that create the effect of a subsidy-such as the differential application of export taxes and differential rebate of value-added taxes for inputs and outputs in an industry's supply chain-do not fit the current legal definition of a subsidy.

Second, the evidentiary burden on those challenging subsidies is too high. This is particularly true when the subsidies are provided in nontransparent economies, such as China. Moreover, many challengers fear extra-WTO retribution from China when contesting state subsidies.

Third, the system of voluntary notifications of subsidies does not work. Many countries have ignored entirely or been delinquent in providing the required notifications of their subsidies. In addition, the lack of agreement as to what constitutes a subsidy likely contributes to the poor notification record of some countries. At best, they may notify only what they perceive to be subsidies.

The final concern is that the remedies are inadequate. One type of remedy, countervailing duties (CVDs), is available only if the subsidized goods are being imported into a country that has a domestic industry that makes similar products and can demonstrate that it is being injured by the subsidized imports. Even then, the resulting CVD may only deflect subsidized exports into third markets and divert sourcing of imports from other third markets. The result for trade flows is essentially arbitrage. The result for policy is a missed opportunity to tackle the

\footnotetext{
${ }^{1}$ United States Trade Representative, "Joint Statement by the United States, European Union, and Japan at M C11," December 12, 2017, Buenos Aires. See also USTR's Joint Statements of the Trilateral M eeting of the Trade M inisters of the United States, European Union, and Japan, issued M ay 23, 2019, Paris; January 9, 2019, Washington; September 25, 2018, New York; and M ay 31, 2018, Paris. See also The Economist, 'The World Trading System Is Under Attack. But a Peace Plan M ay Be Emerging', July 19, 2018.
} 
underlying unfair competition and overproduction arising from the subsidy. Experiences with steel, aluminum, and even solar panels are three recent and telling examples.

A second type of remedy, via formal WTO dispute settlement, only becomes relevant if a WTO member demonstrates that subsidies are causing serious prejudice to its interests. In these cases the subsidizing member is generally asked to withdraw or "take appropriate steps to remove the adverse effects" of the subsidy. ${ }^{2}$ But given that WTO remedies are only prospective, the removal of the adverse effects of a subsidy may often have little practical economic impact in the markets for the relevant goods. The remedy arrives too late.

These and other constraints have likely contributed to reluctance to use formal WTO dispute settlement to address China's subsidization policies. Instead, the policy response has been to turn to tariffs-first through increased use of countervailing duties, and then arguably through other tariffs implemented during the US-China trade conflict that escalated in $2018 .^{3}$

Despite current political momentum for negotiators to take on China's subsidies, there are competing concerns. The first is simply that the economic scope of the problem is not well defined. Similar circumstances arose in the 1980s in efforts to bring new rules for agriculture into the multilateral system. That conundrum was solved, in part, when the Organization for Economic Cooperation and Development (OECD) was tasked with developing new methods to measure the variety of agricultural subsidy policies deployed across countries and sectors and then consistently reporting them. ${ }^{4}$ Policymakers then relied on the OECD's analysis in framing the agriculture negotiations. The failure to adopt a similar approach for industrial subsidies could lead negotiators to focus on disciplining the wrong things.

Second, unlike tariffs, constraints on domestic subsidies run the risk of preventing countries from sometimes using first-best economic policies. Additional political backlash could arise if new rules are seen to excessively restrain national sovereignty over legitimate economic policy. Tightening subsidy disciplines could push some of the inevitable political-economic demands for subsidies into alternative, less transparent, and more distorting policy instruments.

This paper is organized as follows. Section 2 provides a brief history of subsidy disciplines in the GATT and WTO. Section 3 describes the major political and economic concerns about subsidies, particularly those relating to China. Section 4 explores the extent to which the ineffectiveness of the WTO's Agreement on Subsidies and Countervailing M easures (ASCM) itself is at the root of the problem. Section 5 provides a legal-economic assessment of a number of proposals for new WTO rules on subsidies. Section 6 concludes with a short discussion of the additional challenge of implementing any new rules.

\footnotetext{
${ }^{2}$ Article 7.7 of the Agreement on Subsidies and Countervailing M easures.

${ }^{3}$ See Chad P. Bown, 'The 2018 US-China Trade Conflict After 40 Years of Special Protection', 12 China Economic Journal (April 2019): 109-136.

${ }^{4}$ See the Agricultural Economics Society Presidential Address given by OECD official Wilfrid Legg, 'Agricultural Subsidies: Measurement and Use in Policy Evaluation', 54 Journal of Agricultural Economics (July 2003): 175--201.
} 


\section{A Brief History of Subsidy Disciplines in the GATT and WTO: Concerns before China}

The initial focus of the 1947 General Agreement on Tariffs and Trade (GATT) was to get countries to convert nontariff barriers into tariffs, bind those tariffs, and multilaterally negotiate their reduction. The typical result was a reciprocal increase in market access.

Yet even from the GATT's beginning emphasis on tariffs, there was recognition that countries could replicate the effects of a tariff through a combination of other policies. In the simplest case, the economic effects of a 5 percent import tariff can be identically duplicated through the combination of a 5 percent consumption tax and a 5 percent production subsidy. Thus, the GATT would require something to prevent countries from taking away-via domestic subsidy and tax policies-the market access concessions implied through negotiated tariff reductions.

At the same time, rules on subsidies would require more nuance than the GAT's approach to tariffs. First, targeted subsidies can be a first-best domestic policy to address market failures or externalities in ways that tariffs cannot. For example, to the extent that research and development $(R \& D)$ generates positive externalities, they will be underprovided in a competitive market, and thus merit an appropriately sized subsidy. Second, the new technologies or scientific knowledge that create demand for these subsidies evolve over time in ways that require policy flexibility. This implies that narrow subsidy binding limits-a potential analogue to rigid tariff bindings-would be inefficient. Third, even in the ranking of policy instruments, a subsidy is not as bad as a tariff because the latter distorts both production and consumption decisions. Fourth, subsidies may be subject to greater political-economy discipline because they face budget financing constraints that tariffs do not.

Whether and how to discipline subsidies has thus been a divisive issue from the GATT's inception. ${ }^{5}$ The most that could be agreed in 1947 was the language in Article XVI requiring parties to notify the GATT Secretariat of any domestic subsidies that might affect exports and a more general statement that countries "should seek to avoid" the use of export subsidies. In terms of enforcement, the GATT provided two potential avenues to attack subsidies. There was a direct remedy for countries importing the subsidized good, as Article VI allowed for the imposition of a countervailing duty calibrated to the portion of production costs covered by subsidies. ${ }^{6}$ But the remedy was only indirect for countries whose exports were adversely affected by subsidies, with recourse limited to filing nonviolation nullification and impairment (NVNI) disputes.

Those meager disciplines were tightened in the Tokyo Round of negotiations (1973-79), resulting in the Agreement on Interpretation and Application of Articles VI, XVI and XXIII of the General Agreement on Tariffs and Trade (the "Subsidies Code"). The Subsidies Code contained provisions making export subsidies (with exceptions for agriculture exports and for developing countries) a per se violation of the rules and added a requirement that countries wishing to

\footnotetext{
${ }^{5}$ See Andrew L. Stoler, 'Evolution of Subsidies Disciplines in GATT and the WTO', 44 Journal of World Trade (2010) 797.

${ }^{6}$ See Douglas A. Irwin, Historical Notes on Subsidies and the Trading System, What Shapes the Law? Reflections on the History, Law, Politics and Economics of International and European Subsidy Disciplines, Luca Rubini and Jennifer Hawkins (Eds.), Florence: European University Institute (2016).
} 
apply countervailing duties had to first prove that their domestic industry was injured by the subsidized imports. ${ }^{7}$ The Subsidies Code was negotiated as a plurilateral agreement with GATT members deciding for themselves whether to join.

The Uruguay Round of negotiations (1986-93) ultimately resulted in the WTO and with it the ASCM . The ASCM applies to all WTO members as part of the single undertaking and includes a definition of a subsidy: measures that entail a "financial contribution" from a "government or public body" that confer a "benefit" on the receiving firm. However, apart from per se prohibited export subsidies, only "specific" subsidies were subject to WTO action, and then only if they caused "adverse effects" to another WTO member. Finally, members were supposed to report all subsidies in a timely manner to the WTO, but no penalties would be applied for delinquent notifications.

At the time, the ASCM introduced, on a trial basis, the concept of "green light" subsidies that would not be actionable even if they were specific and caused adverse effects. These included $R \& D$ subsidies, regional development subsidies, and subsidies to comply with environmental regulations. But the trial period expired after five years and was not renewed.

On a related track, the Uruguay Round brought a number of new agriculture disciplines into the multilateral system for the first time. Many challenges to constraining domestic agricultural policies have important parallels with the subsidy concerns involving China today. These include defining and measuring the scope of the economic distortions that arise because governments have used a multitude of policy instruments to support domestic production. For agriculture, the distortions resulted from domestic price supports, input subsidies, land controls, state trading, domestic and export subsidies, variable levies, tariffs, quotas, and more.

Similar to the ASCM, the WTO Agreement on Agriculture also sought to classify certain types of subsidies based on whether they were trade distorting. One policy goal was to reorient agricultural policies toward direct subsidies that could be "decoupled" from market prices, production, or input use and pushed toward direct income payments or R\&D support.

For these reasons and more, the newfound collection of subsidy rules also meant that the Uruguay Round created problems. The additional constraints on first-best use of subsidies created incentives for some governments to turn instead to second-best instruments, including tariffs and even more indirect and nontransparent policies. ${ }^{8}$

\section{Contemporary Political-Economic Concerns about Subsidies and China}

The ongoing, trilateral work program of the United States, European Union, and Japan is evidence of new political momentum to create more discipline, particularly in light of China's

\footnotetext{
${ }^{7}$ See John D. Greenwald, Negotiating Subsidies in the GATT/WTO: The Tokyo Round, What Shapes the Law? Reflections on the History, Law, Politics and Economics of International and European Subsidy Disciplines, Luca Rubini and Jennifer Hawkins (Eds.), Florence: European University Institute (2016).

${ }^{8}$ See Kyle Bagwell and Robert W. Staiger, 'Will International Rules on Subsidies Disrupt the World Trading System?' 96 American Economic Review (2006): 877-95 and Alan 0. Sykes, 'The Economics of WTO Rules on Subsidies and Countervailing M easures', in Patrick F. J. M cCrory, Arthur E. Appleton, and Michael G. Plummer, eds., The World Trade Organization: Legal, Economic, and Political Analysis. Vol. 2. (2005) Springer: New York.
} 
growing importance to the global economy and international trading system, as well as the perceived inability of the WTO to regulate subsidies effectively. This section provides a framework to examine political-economic reasons why China's subsidies are of concern.

\subsection{General Economic Concerns with China's Subsidies}

The basic economic starting point to evaluate China's subsidies is to consider a standard, twocountry model with competitive markets and no "frictions" that inhibit resources from being deployed anywhere in either economy. The model also treats China as a "large" economy because its policies alone can generate changes in economic activity in foreign markets.

Yet understanding the root of the problem-real or perceived-requires an analysis that goes beyond this framework, because on net, China's subsidies in such a setting are typically found to be beneficial for the overall economic well-being of its trading partner. While there are distributional consequences-such as losses to the sector that competes with imports in the trading partner-those economic losses are more than offset elsewhere, including by gains to its consumers through lower prices.

Thus, consider three important ways in which reality may differ from this simple model.

First, the competition with China is often in third-country markets. The exporting country can be worse off on net if China's subsidies displace its exports in a common foreign market.

Second, markets are not always competitive. First, it is possible that subsidies could drive out existing competitors in some sectors, which could be problematic if there are barriers to reentry. As described below, there are important instances in which China has shown a willingness to exploit its market power by restricting exports and raising prices for foreign consumers. Second, in other sectors that are very concentrated, subsidies could be used strategically to give China a first-mover advantage that would work to shift profits from exporters in other countries. ${ }^{9}$

Third, markets are not always frictionless. There is evidence of considerable adjustment costs to workers and companies exposed to trade-related economic shocks. ${ }^{10}$ Consider, for example, a major reduction to global demand for a product that, all else equal, would cause a proportionate reduction in output-and in the number of workers and companies-in all producing countries, resulting in layoffs and bankruptcies. If China's subsidy system prevents layoffs and bankruptcies and maintains production, it not only fails to bear its share of the burden of the negative shock, but it pushes more of its cost onto other countries that do not deploy such subsidies.

\subsection{Additional Problems from the Nature of China's Subsidies}

China has important elements of a nonmarket economy and deploys an array of policies that, even though they may not fit the traditional WTO definition, can have the economic effect of a

\footnotetext{
${ }^{9}$ Nevertheless, subsidy limits in the case of a Cournot duopoly may not improve the economic well-being of the world, even though they may be jointly beneficial for the two exporting countries.

${ }^{10}$ See David H. Autor, David Dorn, and Gordon H. Hanson, 'The China Shock: Learning from Labor M arket Adjustment to Large Changes in Trade', 8 Annual Review of Economics (2016): 205-40.
} 
subsidy. Given that nonmarket economies became part of the GATT in the 1960s, not all such problems are new to the trading system. ${ }^{11}$ But today's concerns are heightened by China's economic size and evidence that China is moving even farther from market economy principles under President Xi Jinping. ${ }^{12}$

A recent OECD study uses the aluminum value chain to illustrate how Chinese policies generate subsidized downstream (refined, manufactured) products even though the firms involved may not receive a subsidy, at least in its traditional form. ${ }^{13}$ The OECD estimates that primary aluminum makes up 75 to 86 percent of the costs of downstream, semi-finished aluminum products. Because energy is such a sizable share of the total cost of primary aluminum, subsidized coal is a key benefit. Chinese state-owned commercial banks provide other subsidized inputs in the form of below-market financing to downstream firms because they are not subject to hard budget constraints. Furthermore, China has export restrictions and does not fully rebate the value-added taxes (VATs) on upstream primary aluminum. Yet the downstream, refined aluminum manufacturers do not face export restrictions and do receive VAT rebates. ${ }^{14}$ The combined effect of the policies is to create seemingly sizable economic subsidies received by downstream refined aluminum manufacturers when viewed from the conditions of competition faced by foreign peers.

Allegations of Chinese subsidies also often focus on the role of SOEs. In addition to commercial banks and energy companies, other upstream SOEs may provide key inputs to downstream firms at below-market prices. An oft-cited example is steel, in which an SOE provides subsidized hot rolled steel, an input that benefits all downstream Chinese steel manufactures, regardless of the market competition or privatization of the downstream segment of the industry.

Even for "private" Chinese firms, the close association of the state and industry in the Chinese system raises questions about which firms are truly private. Concerns arise if management includes board members who are Communist Party officials and may feel compelled to eschew

\footnotetext{
${ }^{11}$ See John H. Jackson, The World Trading System: Law and Policy of International Economic Relations. Cambridge, M A: MIT Press (1989, p. 218), and "M any of the unfair trading practices ... have been considered unfair because they interfere with or distort free-market-economy principles. GATT, of course, was largely based on such principles. It is not surprising, therefore, that it is often difficult to apply GATT's trading rules to nonmarket economies."

${ }^{12}$ See Nicholas R. Lardy, The State Strikes Back: The End of Economic Reform in China? Washington: Peterson Institute for International Economics (2019).

${ }^{13}$ OECD, M easuring Distortions in International M arkets: The Aluminium Value Chain. Trade Policy Papers, no. 218. Paris: OECD Publishing (2019).

${ }^{14}$ For related WTO disputes over the application of trade remedies on imports from countries deploying differential export tax schemes, see Meredith A. Crowley and Jennifer Hillman, 'Slamming the Door on Trade Policy Discretion? The WTO Appellate Body's Ruling on M arket Distortions and Production Costs in EU-Biodiesel (Argentina). 17 World Trade Review (2018): 195-213, and Carolyn Fischer and Timothy M eyer, 'Baptists and Bootleggers in the Biodiesel Trade: EU-Biodiesel (Indonesia)," World Trade Review (forthcoming). For VAT rebates, see Simon Evenett, Johannes Fritz and Yang Chun Jing, 'Beyond dollar exchange-rate targeting: China's crisis-era export management regime', 28 Oxford Review of Economic Policy (2012): 284-300; and Julien Gourdon, Laura Hering, Stéphanie M onjon, and Sandra Poncet. 'Trade policy repercussions: The role of local product spaceEvidence from China. HAL working paper Hal-02065779 (2019).
} 
adherence to market incentives in order to achieve goals set out in China's explicit industrial policy for the firm's sector, including through the Made in China 2025 policy. ${ }^{15}$

\subsection{Concerns about the Ineffectiveness of WTO Remedies to Address China's Subsidies}

Alongside its tremendous and sustained period of economic growth and development, China has rapidly become a dominant global supplier of a number of heavily traded industrial products. These include steel, aluminum, and solar panels-sectors in which China has been accused of mass subsidization. ${ }^{16}$

In steel and aluminum, China increased its share from roughly 25 percent to over 50 percent of global production and capacity between 2002 and 2017. The initial increase in capacity helped fuel its domestic economy when China was growing at 10 to 12 percent per year, urbanizing and investing in domestic infrastructure projects. For many, China's expansion was welcome, even if it was partially subsidized or state driven, as its demand pushed up world metal prices and fueled demand for imported inputs such as coal and iron ore from countries such as Australia and Indonesia. However, when China's growth slowed to under 7 percent, its domestic demand for these products fell and it began exporting an ever-increasing share of metals to the world market.

The traditional WTO-permitted remedies did little to solve the problem involving steel, aluminum, or solar panels. The United States imposed enough antidumping and countervailing duties by 2017 to cover over 90 percent of its imports from China of each sector (figure 1). Yet China continued its export expansion into third markets and the United States continued to import low-priced products. In the case of steel and solar panels, the pressure increased to impose protection on third countries. The share of US steel imports from third countries, for example, subject to antidumping increased from roughly 30 percent in 2012 to over 50 percent by 2017 (panel a). ${ }^{17}$ Then, in 2018, the US administration imposed tariffs on virtually all imports of steel and aluminum under the guise of "national security" pursuant to Section 232 of the Trade Expansion Act of 1962. And for solar panels in 2018, the US administration imposed comprehensive protection under Section 201 of the Trade Act of 1974.

The prior buildup of US antidumping and countervailing duties had resulted in a predictable trade response. To the extent that different national varieties are relatively substitutable products, a US tariff on China alone could lead to trade deflection (increased Chinese exports to

\footnotetext{
${ }^{15}$ See M ark Wu, 'The 'China, Inc.' Challenge to Global Trade Governance', 57 Harvard International Law Journal (2016): 261-24.

${ }^{16}$ See 'The Effect of Imports of Steel on the National Security: An Investigation Conducted under Section 232 of the Trade Expansion Act of 1962, as Amended,' US Department of Commerce, Bureau of Industry and Security, Office of Technology Evaluation, January 11, 2018; 'The Effect of Imports of Aluminum on the National Security: An Investigation Conducted under Section 232 of the Trade Expansion Act of 1962, as Amended', US Department of Commerce, Bureau of Industry and Security, Office of Technology Evaluation, January 11, 2018; and 'Crystalline Silicon Photovoltaic Cells (Whether or Not Partially or Fully Assembled into Other Products)', Publication 4739, US International Trade Commission, November 2017.

${ }^{17}$ See Chad P. Bown 'Trump's Steel and Aluminum Tariffs Are Counterproductive. Here Are 5 M ore Things You Need to Know', PIIE Trade and Investment Policy Watch, M arch 7, 2018.
} 
a third market such as Japan) and trade diversion (increased US imports from Japan of a close substitute squeezed out of the Japanese market because of the Chinese imports). ${ }^{18}$ And for the more upstream varieties, third countries may have processed the Chinese imports into refined downstream products for export. As such, they received below-market-priced inputs, equivalent to an economic subsidy, but provided by an entity other than the government.

One effect of the alleged subsidies has been a massive strain on the trading system. The 2018 US tariffs on steel and aluminum in particular mostly hit third countries, including Canada, Mexico, and EU members, none of which were accused of subsidizing, and all of which retaliated against US exports. The result has been a major wave of WTO litigation challenging both the US tariffs and the trading partner countertariffs. ${ }^{19}$ Some countries then imposed their own trade restrictions on steel and aluminum-generating more friction with third-country exporters-out of concern that trade shut out of the US market would be deflected into their markets.

This entire episode has contributed to the weakening of the rules-based trading system without addressing the subsidies themselves.

\subsection{Concerns about Measuring the Size of the Economic Problem}

There is considerable pressure on policymakers to address Chinese subsidies, but how large is the economic problem? The economic magnitude of the subsidies is unknown, as is the extent of the spillover costs of China's subsidies for other countries. ${ }^{20}$

This conundrum has parallels with the challenge facing agricultural negotiators in the 1980s. Mostly undisciplined by the GATT system's rules, for decades governments had deployed an array of policies that ended up distorting agricultural markets. The variety of instruments made it difficult for negotiators to understand which policies were most harmful and thus to prioritize which to discipline.

In retrospect, one important way that the multilateral system made progress in dealing with agriculture was through a concerted effort to collect new data and develop new techniques to define the scope of the economic problem. The OECD began to construct what became known as Producer and Consumer Support Estimates (PSEs and CSEs) to inform the debate about the aggregate size of the subsidies within and across countries and sectors. Once an agreed-upon methodology was developed, the OECD began reporting annual estimates of the size of these policies. $^{21}$

\footnotetext{
${ }^{18}$ For evidence of its general empirical relevance, see Chad P. Bown and M eredith A. Crowley, 'Trade Deflection and Trade Depression', 72 Journal of International Economics (2007): 176-201.

${ }^{19}$ For China's response to the US imposition of tariffs on solar panels, see Chad P. Bown, 'China's Latest Trade M aneuver Is Worrying. Here's the Story', The Washington Post, February 6, 2018.

${ }^{20}$ The analysis of Lardy (2019, fn. 13) finds the subsidies impose large costs on China's own economy through lower productivity and growth.

${ }^{21}$ See Legg (fn. 4). The first of the now annual reports was OECD, 'National Policies and Agricultural Trade,' Paris: OECD Publishing (1987).
} 
In the current context of industrial subsidies, the OECD has made a step in the right direction by providing cross-country estimates of the size and variety of subsidies in the aluminum sector. But the system requires a similar economic analysis for other industries. And inevitably, this requires countries, including the United States, to face enhanced assessment of the types of subsidies they provide, including those at the state and local levels.

\section{The Ineffectiveness of the ASCM}

This section examines complaints that the ASCM has proven ineffective in addressing these and other types of subsidies.

\subsection{The Definitional Problem-State-Owned Enterprises}

Examination of subsidies almost always begins with the tricky question of how to define them. Until the Uruguay Round, there was no explicit definition of a subsidy, so ASCM Article 1which defines a subsidy as a "financial contribution by a government or any public body" that "confers a benefit" on the recipient, along with a specific list of different forms of financial contributions-was groundbreaking.

Because "conferring a benefit" requires showing that the recipient is better off than it would have been if it received financial contributions at market rates, most countries took the view that benefits could not be measured in nonmarket economies. For the United States, that position changed in 2007 when it began to apply CVDs to imports from China if the Chinese producer had received subsidies or input materials from SOEs. ${ }^{22}$ Given the volume of Chinese imports and amount of subsidies, such actions contributed to the sharp and sudden increase in US CVDs: As figure 2 illustrates, CVDs covered nearly 7 percent of US imports from China by 2018. Because the CVDs almost always hit the same products covered by simultaneously imposed antidumping duties (see also figure 2), this has not affected the level of US imports from China targeted by trade remedies overall, only the (combined) size of duties imposed. ${ }^{23}$

China reacted negatively to US CVDs imposed on its exports, particularly when the subsidies were provided by an SOE rather than by the government itself. It challenged the US practice at the WTO, claiming that support or inputs provided by an SOE could not be considered subsidies since only financial contributions by "governments or public bodies" (not SOEs) met the definition. In ruling on China's challenge, the Appellate Body interpreted "public body" to mean governments or governmental entities that exercise governmental functions-i.e., that the

\footnotetext{
${ }^{22}$ Prior to 2007, the United States did not apply its CVD law to countries considered to be nonmarket economies (NMEs) based in part on a conclusion by the Department of Commerce that it could not determine where government action began or ended and therefore could not specifically identify subsidies. In 1986 the USCourt of Appeals for the Federal Circuit, in Georgetown Steel Corp. v. United States, upheld this interpretation of the CVD statute as reasonable. In 2006 Commerce changed its position, accepting a petition seeking a CVD on imports of coated free-sheet paper from China. Commerce distinguished the current Chinese economy from the Soviet-style economies at issue in Georgetown Steel and found that the imported Chinese paper was subsidized.

${ }^{23}$ Some of the US turn toward CVD use after 2007 was likely as insurance, to blunt the potential impact if the United States adjusted its antidumping policy in light of the 2016 deadline involving China's NME status. For a discussion, see Chad P. Bown, "Should the United States Recognize China as a Market Economy?" Peterson Institute for International Economics PIIE Policy Brief 16-24, (December 2016).
} 
entity must possess, exercise, or be vested with "governmental authority" and perform a "governmental function." ${ }^{24}$ This interpretation effectively removes contributions by Chinese SOEs from the definition of a subsidy.

An emphasis on entities exercising a governmental function also exclusively focuses scrutiny on the characteristics of the "giver" of the subsidy rather than the purpose or the effect of the "gift." As such, it makes subsidy disciplines difficult to apply in economies where there is a blurred line between government and the private sector. This is particularly true in China, for a variety of reasons described earlier, including that Communist Party officials may sit in management positions at supposedly private companies.

The Appellate Body's "public body" decision raised further concerns by presuming that a realistic fallback exists in the ASCM for those times when the government "entrusts or directs" a private body to provide the subsidy rather than doing it directly, notwithstanding the virtual impossibility of proving such entrustment or direction in any but the most transparent of countries. ${ }^{25}$

Equally contentious is the definition of an SOE for purposes of determining whether it received, or more importantly provided, a subsidy in the form of cheap inputs to a downstream producer. There has been considerable criticism of definitions that focus too strictly on "ownership," largely because ownership often does not result in control or the ability to direct the purchasing or selling decisions of the enterprise, and the absence of ownership does not mean the absence of government control. ${ }^{26}$

\subsection{The Definitional Problem - Subsidies Effected through Other Policies}

Further problems arise from government policies that indirectly result in subsidies. These can include differential taxes across value chains or differential rebates of VATs or export taxes, all of which can have the effect of subsidizing downstream (or upstream, depending on the differential) producers. Such policies can, for example, make input materials artificially cheaper for domestic firms relative to foreign competitors. While WTO rules prohibit export quotas, there are no general restrictions on export taxes and the ASCM expressly permits tax rebates on exports as long as such rebates do not exceed the amount of taxes paid on domestic sales. ${ }^{27}$

The exception to the general WTO failure to discipline was respect to some export taxes in China. As its accession to the WTO was being negotiated, China had in place an extensive network of export taxes and tax rebate schemes. Many WTO members were concerned that the Chinese government could use such export restraints to create scarcity in global marketsresulting in higher world prices-of raw materials and other inputs, and at the same time

\footnotetext{
${ }^{24}$ United States-Definitive Anti-Dumping and Countervailing Duties on Certain Products from China, WT/DS379/AB/R.

${ }^{25}$ Ibid. and ASCM Article 1.1(a)(1)(iv).

${ }^{26}$ OECD Guidelines on Corporate Governance of State-owned Enterprises, Paris: OECD Publishing (2015).

${ }^{27}$ GATT Article XI eliminates quotas (but not duties or taxes) on exports, while footnote 1 to the ASCM permits exemptions from taxes or rebates of taxes paid for exports so long as such rebates or exemptions do not discriminate in favor of domestic products.
} 
provide domestic Chinese companies with a significant advantage by way of a sufficient and subsidized local supply. The result was Paragraph 11.3 of China's Protocol of Accession, which banned export taxes other than on a specified list of products. However, China continued to apply export taxes in violation of its protocol commitment until challenged at the WTO. ${ }^{28}$ The (unsuccessful) attempt by China to justify its export tax schemes and the example of aluminum described above illustrate why concerns remain that China's deft use of export restraints effectively subsidizes exports of its downstream products.

Finally, the ASCM 's subsidy definition focuses disciplines on harm to competitors-whether in the form of injury to domestic industries or adverse effects more broadly-rather than on harm to market competition or to global public goods. ${ }^{29}$ Establishing new and widely accepted disciplines may require policymakers to more clearly delineate such subsidies-possibly carving out those that contribute to positive global goods while condemning those that harm the global commons. Examples of the latter could include subsidies for fossil fuels and those that lead to overfishing. ${ }^{30}$ Whatever subsidy rules are agreed will also likely require provision of both regulatory space and proper incentives to address climate change.

\subsection{The Evidence Problem}

Numerous aspects of the ASCM make it difficult for complaining countries to meet their burden of proof to demonstrate that prohibited or actionable subsidies were in fact provided. This is particularly true with respect to (i) demonstrating governmental control over an entity as part of proving that the entity may be a "giver" of a subsidy, (ii) showing that actions by a private entity were done at the "direction" of the government, (iii) proving a benchmark against which to judge whether a financial contribution confers a benefit by providing funds or resources at below-market prices, (iv) and proving that any adverse effects were caused by the subsidies rather than by other factors.

The first two require knowledge of government actions and documentation of what the government did, as well as when and sometimes why. Obtaining such evidence, particularly in nontransparent economies, is extraordinarily difficult, as few government officials put such information into the public record. Furthermore, it is often challenging for policymakers in trading partners to get their firms to provide the necessary evidence to pursue a case. ${ }^{31}$ Multinational companies often fear exposure to extra-WTO Chinese retaliation. Firms may also be concerned about the safety of turning over business confidential information, even to their own governments, especially given heightened concerns about cyberhacking.

\footnotetext{
${ }^{28}$ See China-Raw Materials, WT/DS394, WT/DS395, WT/DS398 (adopted February 22, 2012); China-Rare Earths, WT/DS431, WT/DS432, WT/DS433 (adopted August 29, 2014).

${ }^{29}$ See Gary Horlick, How Subsidies Rules Have Been Shaped, What Shapes the Law? Reflections on the History, Law, Politics and Economics of International and European Subsidy Disciplines, Luca Rubini and Jennifer Hawkins (Eds.), European University Institute (2016).

${ }^{30}$ For a discussion of the difficulty of defining global public goods, see Inge Kaul, Donald Bondin and Neva Nahtigal, Understanding Global Public Goods: Where We Are and Where to Next, Cheltenham, UK: Edward Elgar (2016).

${ }^{31}$ See Chad P. Bown and Soumaya Keynes, 'US Trade Policy before Trump, with Ambassador Michael Froman', Trade Talks podcast episode 93 (July 19, 2019).
} 
The third challenge is often trickier, as it requires comparisons to a market benchmark, which may not exist in countries whose government dominates the economy. Even proving such domination can be difficult when the government's heavy-handed influence interferes with market forces or directs functions in subtle ways. ${ }^{32}$

The last issue-causation-is often the hardest, as many factors affect prices, wages, employment, production, and demand. Yet the Appellate Body's rulings indicate that harms caused by factors other than subsidies must be separated out to ensure that any injury found is properly attributable to subsidized imports. Evidence of causation often requires sophisticated econometric models that are expensive, data intensive, and can yield indeterminate results, even when applied to the relatively "clean" setting of a market economy. ${ }^{33}$

\subsection{The Notifications Problem}

At an October 2018 meeting of the Subsidies and Countervailing Measures Committee, Chair Luis Fernández of Costa Rica, stated, "The chronic low compliance with the fundamental obligation to notify subsidies constitutes a serious problem in the proper functioning of the Agreement." He reported that 78 WTO members (48 percent) had not yet made subsidy notifications that were due in 2017, 63 members (38 percent) had not made notifications due in 2015 , and 56 members ( 34 percent) had yet to deliver their notifications due in 2013. ${ }^{34}$

With over a third of members at least five years behind in subsidy notifications, the notification problem becomes clear.

\subsection{The Remedy Problem}

Perhaps the biggest reason that the ASCM has been unable to adequately police subsidies, particularly in China, lies at the feet of the remedies available under the WTO rules. The ASCM provides for three different remedies once a subsidy has been found. For prohibited subsidies (those contingent on exports or on the use of domestic over imported goods), the remedy is to "withdraw the subsidy without delay." ${ }^{35}$ For all other subsidies, the ASCM provides two options: the imposition of countervailing duties if the subsidized goods are coming into a member's market and causing injury to its domestic producers, with the amount of the duty equal to the portion of the cost of production that has been covered by the subsidy, or the commencement of a serious prejudice case at the WTO if the damage from trade in the subsidized product is causing harm in the exporting country or in a third-country market.

\footnotetext{
32 "On each of the six dimensions-state assets oversight, financial sector organization, role of state planning, forms of corporate networks, political party involvement, and state-private sector linkages-China stands apart. When considered in their totality, this unique combination of elements gives rise to 'China, Inc.' M ark Wu, fn. 15.

${ }^{33}$ For a discussion of the importance of economic models in subsidy cases, see Ray A. Goldberg, Robert Lawrence, and Katie Milligan, 'Brazil's WTO Cotton Case: Negotiation Through Litigation', Harvard Business School, N9-905405, September 23, 2004.

${ }^{34}$ WTO Committee on Subsidies and Countervailing M easures M eeting, October 23, 2018.

${ }^{35}$ While the text "withdraw the subsidy without delay" appears clear, there has been substantial litigation over whether the entire subsidy must be withdrawn or only the parts that are contingent on exports. What time period constitutes "without delay" is specified by the panel in each case (Article 4.7) and is generally a short period (90 days, for example, in Brazil-Aircraft (WTW/DS46/ABR/, adopted August 20, 1999).
} 
One problem with countervailing duties is that they are available only in countries that import the product and that have a domestic industry making comparable goods. They also require a fairly extensive (and expensive) investigation. A relatively long time can be required for the investigating authorities to collect the data, investigate the subsidies, and rule on the complaint. The investigation also often involves extensive solicitation of data from the domestic industry and subsidizing government, with ongoing controversy over its appropriate use and what to do when such information is not forthcoming. Moreover, imposing such duties may simply push the subsidized goods into other markets, thus suppressing prices elsewhere. The recent experience with steel, aluminum, and solar panels is that the remedy often proves ineffective, particularly if the goal is to discourage the initial granting of subsidies.

The problem with serious prejudice cases is that remedies in the WTO are only prospective. The requirement to "remove the adverse effects of the subsidy" often does little to dismantle the capacity that has been built to produce the subsidized goods in the first place. M oreover, most of the elements of proof of serious prejudice-whether showing displacement in third-country markets or price suppression or depression-have a temporal element built into them. ${ }^{36}$

This temporal lag means that serious prejudice cases likely cannot be brought until many years after the subsidies have allowed factories to become fully functional, selling their products in third-country markets in sufficient quantities to cause "displacement" of others, or with such sales occurring over a long enough period to observe a "depression" in prices. Even nonrecurring subsidies-e.g., to install capacity-can have long-felt economic effects. ${ }^{37}$ Add the time required to litigate a WTO dispute, and altogether it can take a complainant a minimum of five or six years to bring and win a subsidies challenge and achieve compliance. ${ }^{38}$

\section{Proposals for New Subsidy Rules}

For all these reasons, there has been a push for new subsidy disciplines in the WTO. The following are an assessment of some of the proposals.

\subsection{Measure, Diagnose, and Define the Problem, and Then Prioritize}

First, better information is needed through economic analysis to determine which subsidies are problematic in terms of the economic distortions they impose on other countries. Of relevance

\footnotetext{
${ }^{36}$ For example, proving that price depression has occurred requires showing that prices have declined over a period of years- often either three or five years.

${ }^{37}$ For a discussion of nonrecurring subsidies and the ASCM, see Gene M. Grossman and Petros C. M avroidis, 'United States-Imposition of Countervailing Duties on Certain Hot-Rolled Lead and Bismuth Carbon Steel Products Originating in the United Kingdom: Here Today, Gone Tomorrow? Privatization and the Injury Caused by NonRecurring Subsidies,' in Henrik Horn and Petros C. M avroidis, eds., The WTO Case Law of 2001: The American Law Institute Reporters' Studies, ed. Cambridge University Press (2003): 170-200.

${ }^{38}$ The dispute settlement process alone can take four years or more, assuming 18 months for a panel report, 5 months for an appeal, 15 months as a reasonable period of time for compliance, and 6 months of lags between the various steps in the WTO dispute settlement process. The time frame could be substantially less if the case involved only prohibited subsidies. See also Joost Pauwelyn, "New Proposal to Strengthen WTO Notification Requirements: From Dispute Settlement to Compliance Regime," International Economic Law and Policy Blog, April 3, 2019.
} 
are lessons learned in the 1980s when the OECD developed an approach to help clarify the scope of agricultural subsidies. And new disciplines would certainly be more politically palatable-as well as sustainable-if applied to all forms of subsidies and all of the major economies, not just China.

Next, as was done with the WTO's Agreement on Agriculture, members could try to create categories of "permitted" or "green light" subsidies that would fall outside the scope of the ASCM disciplines, "red light" or prohibited subsidies as noted above, and "amber light" subsidies for all others. Doing so would provide policy space for members to negotiate the types of subsidies in each category, particularly for "green light" subsidies, which could include those that promote the public good or are directed at addressing climate change. ${ }^{39}$

Establishing an amber box-which would include subsidies that likely distort production and trade-would require a commitment by members to limit their total spending on such subsidies, with the largest subsidizers potentially committing to reduce their amber light subsidies over a set time period. As with the Agreement on Agriculture, certain de minimis levels could be agreed upon to exclude a specific amount of subsidies from scrutiny as a quid pro quo for acceptance of limits and required cutbacks from existing levels.

Such an approach would clarify to China that the international community finds troubling the market-distorting aspects of its subsidy policies. It would encourage China, if it feels the need to continue subsidizing, to redirect its policies away from those tied to market signals. Separately, it would also require a new process to continually reevaluate permissible subsidies, given advances in scientific knowledge and new evidence on global public goods.

\subsection{Expand the List of Prohibited Subsidies}

Because prohibited subsidies have both a clearer and faster remedy than merely actionable subsidies, expanding their list could add teeth to the ASCM ${ }^{40}$ Currently, ASCM Article 3 limits prohibited subsidies to export subsidies or subsidies contingent on the use of domestic products over imports. ${ }^{41}$ If certain subsidies that are considered more trade distortive, such as those leading to substantial global overcapacity, could be defined and added to Article 3, it would strengthen the ASCM.

\footnotetext{
${ }^{39}$ See M ark Wu, "Re-examining 'Green Light' Subsidies in the Wake of New Green Industrial Policies," (August 2015) http:// e15initiative.org/wp-content/uploads/2015/07/E15 Industrial-Policy Wu FINAL.pdf.

${ }^{40}$ The remedy called for with respect to prohibited subsidies is "withdraw the subsidy without delay" (ASCM Art. 4.7), while the time frame for adoption by the Dispute Settlement Body is cut in half (30 days rather than 60 days for others; ASCM Art. 4.8), the time for appeal is a maximum of 60 days rather than 90 (ASCM Art. 4.9), and all other time periods are cut in half (Art. 4.12). For a discussion of the first case to depart from the GATT and WTO practice of applying remedies only on a prospective basis, see Gavin Goh and Andreas Ziegler, "Retrospective Remedies in the WTO After Automotive Leather," Journal of International Economic Law 6(3): 545-564 (2003).

${ }^{41}$ When the ASCM was crafted, it included a list of subsidies that were deemed to cause serious prejudice, including subsidies to cover operating losses, direct forgiveness of debt, and subsidies covering more than 5 percent ad valorem of a product. However, these provisions expired after five years pursuant to Article 31 and were not extended.
} 
The biggest challenge to such an approach is to reach agreement on what, if any, subsidies deserve to be banned. Perhaps the most salient example involves the fact that there is no universally accepted economic definition of "overcapacity." Any attempt to ban subsidies based on a dubious definition of overcapacity will inevitably become problematic. Once again, overconstraining legitimate use of subsidies risks simply pressuring governments to turn to alternative and second-best policy instruments that could be even more distortive.

\subsection{Redefine "Government or Public Body" in Light of the Chinese Model}

On the definitional issues, consider two alternatives. One is to use WTO rules to adopt a definitive interpretation of "government or public body" that recognizes that a government's ability to direct a corporation's resources (at a favorable price) to one or more privileged recipients can constitute a subsidy, even if the corporation is not engaging in a governmental function. ${ }^{42}$ Another potential solution is to use the same process to define the term "public body" to include any entity that is meaningfully controlled by the government or in which there is evidence of government influence over the enterprise's basic resource allocation decisions.

However, a focus on broadening the definition of "government or public body" will mainly ease use of trade restrictions-i.e., countervailing duties-when the product is directly imported from China. It does little to incentivize removal of the subsidy or to address the underlying problem. And it will hardly result in a major step forward if the main impact of new disciplines is to make the recent experience with steel, aluminum, and solar panels-US tariffs on China, followed by US tariffs on third countries, followed by countertariff retaliation and trade disputes, none of which target the reduction of subsidies-proliferate to other sectors.

Another proposal has been to expand the definition of "prohibited subsidies" to include those that cause harm to market competition or to global public goods. Because prohibited subsidies are considered a per se violation of the WTO rules, no proof of adverse effects is required, and the remedy is to "withdraw the subsidy without delay." If properly defined, many subsidies that lead to substantial overcapacity could be found to present harm to market competition over the long run.

The problem here, of course, is properly defining what subsidies are to be prohibited, especially without first having done the economic assessment and measurement exercise to understand which forms of subsidies are most harmful.

\subsection{Discipline Subsidies Effected through Export Taxes and VAT Rebate Differentials}

Two approaches might be taken to discipline subsidies effected through the use of export taxes or VAT rebate differentials. One would permit countries to use outside benchmarks when seeking to impose antidumping or countervailing duties on imports of downstream products made with input materials that were effectively subsidized through differential export taxes. ${ }^{43}$

\footnotetext{
${ }^{42}$ Article IX.2 of the M arrakesh Agreement Establishing the WTO provides the M inisterial Conference and the General Council with the authority to adopt definitive interpretations, including through a vote by three-fourths of the WTO members. However, no definitive interpretations have been adopted through this procedure to date.

${ }^{43}$ The EU sought to use outside benchmarks when imposing antidumping duties on Argentine biodiesel imports, claiming that the price of the input material-soybeans-was distorted because Argentina maintained a high export tax on soybeans but a low tax on biodiesel exports. The WTO Appellate Body ruled that the resort to
} 
Again, the downside is that such an approach suffers from all of the expense and damage to third-country markets arising through the necessary delay before the problem is addressed. It also presumes that there are appropriate outside benchmarks that can be used in lieu of incountry market prices for the goods in question.

A second approach would expand on and incorporate in the WTO rules applicable to all members the limitations agreed to by China in its protocol-that export taxes are prohibited on all but a specified list of products. Countries could then file a schedule-which presumably could be subject to some form of negotiation and verification-of those products subject to export taxes (or differential VAT rebates). The adoption of such a rule would make clear that the underlying concern is the use of export taxes or differential rebate schemes to hold down the price of input materials as a way to provide a financial contribution to producers using those input materials for finished goods.

\subsection{Revisit the Notion of Applying Remedies Retroactively by Requiring Recipients to Pay Back the Amount of the Subsidy}

Prior to the 1998 WTO dispute over Australia's subsidy to one of its leather producers, it was generally understood that the WTO did not provide for retrospective remedies. ${ }^{44}$ This was based on the view that the WTO was designed to preserve future trading opportunities rather than redress past injury. However, the compliance panel reviewing Australia's export subsidies took the view that the only way to enforce the ASCM prohibition on the grant or maintenance of export subsidies was to restore the situation to what it was before the subsidy was granted, which meant requiring that the grant be paid back in full. This decision was met with considerable criticism, with a number of countries noting that the ruling implied a punishment for private companies, which was not generally a WTO function. It also left governments that had contracted in good faith to provide the subsidies in an untenable position of either meeting their domestic contract obligations or complying with the WTO ruling. ${ }^{45}$

But it remains the case that requiring the repayment of subsidies may be among the strongest deterrents to their being granted in the first place. Indeed, requiring recipients to pay back the entire amount of a subsidy is the policy in the European Union if EU member states grant "state aid" that is later found to be illegal under EU state aid rules. ${ }^{46}$ If retroactive remedies were to become the norm, the repayment requirement would presumably be limited to prohibited

outside benchmarks was not appropriate, so adopting the discipline noted above would effectively overrule this AB decision. EU-Biodiesel (Argentina), WT/DS473/AB/R, adopted October 26, 2016.

\footnotetext{
${ }^{44}$ Australia-Automotive Leather, WT/DS/126/RW, adopted February 11, 2000. See also Tasi-yu Liu, "Remedies for Export Subsidies in the Context of Article 4 of the SCM Agreement: Rethinking Some Persistent Issues," Asian Journal of WTO and International Health Law and Policy 3 (2008)): 21-50.

${ }^{45}$ Canada, Brazil, Japan, the EU, and M alaysia joined Australia in expressing concerns about the decision, with Canada stating that the decision should be considered "a one-time aberration of no precedential value." Meeting of the Dispute Settlement Body, February 11, 2000, WT/DSB/M/75.

${ }^{46}$ See Luca Rubini, The Definition of Subsidy and State Aid: WTO and EC Law in Comparative Perspective, Oxford: Oxford University Press (2009); and EU State Aid Rules and WTO Subsidies Agreement, https://researchbriefings. parliament.uk/ResearchBriefing/Summary/SN06775
} 
subsidies, making it essential that those subsidies be clearly defined. Such repayment obligations would also require some guidelines about how to determine the amount and timing of the repayments, whether they included any form of interest payment, and the creation of an escrow account to ensure full compliance. ${ }^{47}$

\subsection{Establish Bankruptcy and Competition Policy Requirements}

Introducing bankruptcy and competition (antitrust) concepts in the WTO would be an alternative approach to creating stronger disciplines on market-distorting subsidies. ${ }^{48} \mathrm{~A}$ primary source of oversupply and unfair competition in some sectors allegedly derives from chronically underperforming Chinese companies that would have closed had market principles and bankruptcy rules been in place. During bilateral meetings, the United States and China both recognized the link between unfair trade and the lack of strong rules on bankruptcy, but largely left bankruptcy to domestic policy and enforcement procedures. ${ }^{49}$ Now, with more data and a greater understanding that China's bankruptcy regime has not been exerting significant discipline on China's inefficient enterprises, particularly its SOEs, there may be a greater appetite among some WTO members for multilateral rules to set certain basic standards with respect to placing failing enterprises in bankruptcy.

Likewise, the introduction of competition policy rules in the WTO might allow members to challenge, for example, the recent trend of forced mergers among China's largest SOEs. ${ }^{50}$ Large corporations with monopoly or near-monopoly power have always been of economic concern. When those corporations are also SOEs, the fear is not just size and power, but the inability of anyone other than the state to control them.

The WTO could at a minimum seek notifications and data to track the size, scope, and amount of competition among the world's largest corporations. This too could be added to the potential OECD data collection and economic measurement program on industrial subsidies.

\subsection{Address the Evidence Problem}

Establish a set of rebuttable presumptions for countries that believe they have suffered as a result of another member's subsidies is one approach to reduce the burden of evidence from that currently required. For example, the burden of proof would shift to the subsidizing member to show the opposite once a complainant has demonstrated that it is more likely than not that the government directed an entity to provide subsidies or exercised control over an

\footnotetext{
${ }^{47}$ Creation of an escrow account may require ultimate enforcement backed up through tariffs. For a discussion, see Nuno Limão and Kamal Saggi, 'Tariff Retaliation versus Financial Compensation in the Enforcement of International Trade Agreements', 76 Journal of International Economics (2008): 48-60.

${ }^{48} \mathrm{~A}$ number of members had sought to bring at least competition policy into the WTO. At the Singapore M inisterial Conference (1996), a working group was established to study the interaction between trade and competition policy, but no agreement was reached to proceed with any formal negotiations. At the July $2004 \mathrm{M}$ inisterial Conference, work on this issue was formally stopped.

${ }^{49}$ See USTR's 2016 Report to Congress on China's WTO Compliance, p. 5 (https://ustr.gov/sites/default/files/2016China-Report-to-Congress.pdf).

${ }^{50}$ See Lardy (2019, fn. 12) and Caroline Freund and Dario Sidhu, 'Global Competition and the Rise of China, Peterson Institute for International Economics Working Paper 17-3 (February 2017).
} 
$\mathrm{SOE}$, or that, relative to an agreed benchmark, the government offering was at below-market rates.

The idea of rebuttable presumptions is one that could be taken up by the WTO Committee on Subsidies and Countervailing Measures as it would not require a formal change in the rules. Instead, the committee could provide nonbinding guidance to panels as to what level of evidence should be required to create a rebuttable presumption and what types of evidence would serve to effectively refute such a presumption.

\subsection{Consider Counter-Notifications and Other Proposals to Address the Notifications Problem}

The trilateral cooperative countries (US, EU, Japan) and six others (Argentina, Australia, Canada, Costa Rica, New Zealand, and Taiwan) submitted a proposal on April 1, 2019 that would establish clear timelines for noncompliance with notifications requirements. ${ }^{51}$ The proposal would establish administrative penalties for failure to notify, ranging from a bar on chairing WTO bodies to a fine paid into the WTO budget for use in technical assistance, with penalties ratcheting up over time; provision for the WTO Secretariat to do notifications on behalf of members when asked, along with encouragement for members to engage in "counternotifications" by submitting notices of subsidies or other measures that a country should have notified but did not; and the establishment of a working group to devise "systemic and specific improvements" to enhance compliance.

It is too early to tell if other members will embrace this approach, as it represents a significant departure from the past, particularly with respect to automatic findings of noncompliance based on required time frames and sanctions for failure to notify. That nine countries developed such a plan is significant and suggests that some reform to transparency is desired.

While more timely notifications are certainly called for, the bigger problem remains: at best, countries notify only those measures that they themselves believe to be subsidies. If China does not believe that the provision of below-market rate inputs by its SOEs constitutes a subsidy, then it will not notify such subsidies. This gap caused by the "self-declaration" nature of WTO notifications is one reason the United States has emphasized counter-notifications; i.e., other members report to the WTO when they believe China has granted, but failed to notify, a subsidy.

\subsection{Reenvision Enforcement}

A final and admittedly extreme proposal would involve moving enforcement of subsidy disciplines away from the current state-to-state model that underpins WTO commitments. WTO experience has revealed that bilateral enforcement has severe limits, even given economic incentives. Because subsidies negatively affect many trading partners, a free-rider problem arises so that each has an underincentive to invest in the costs of enforcement.

\footnotetext{
${ }^{51}$ JOB/GC/204/Rev. 1, April 1, 2019, "Procedures to Enhance Transparency and Strengthen Notification Requirements under WTO Agreements."
} 
Because many of the benefits that arise from enforcement are enjoyed by other countries, too little enforcement by any one country on its own occurs. ${ }^{52}$

A more efficient means of enforcement would be to shift it to the supranational level. The European Union has moved in this direction with the European Commission enforcing subsidy discipline in member states through its state-aid rules. One way to "enforce" disciplines over China's use of subsidies would be to empower a newly created function of the WTO Secretariat to bring cases independently. Of course, such an approach appears highly politically infeasible at a moment when at least one major member, the United States, is already bemoaning its loss of national sovereignty to the WTO.

\section{Conclusion: Practical Challenges of Implementation}

Many countries appear to share the United States' concerns about the growth of China's SOEs as well as its trade policies that distort economic activity in foreign markets. However, few support the United States' tactics, and its unilateral tariffs have caught many other countries' exports in the cross-fire. The tariffs and countertariffs could disrupt supply chains and slow global growth. For certain, they have already threatened the rules-based trading system. Outside of the United States, there is widespread agreement that a preferable solution would be to craft new rules to be incorporated and enforced within the WTO system.

The first forum that may come up with new approaches to discipline subsidies is the trilateral EU-US-Japan cooperative. It is too soon to tell whether, even among themselves, they will settle on any particular proposals for reform. And even if an agreement among the three can be reached, the next monumental task would involve presenting such a proposal to China as part of a package to resolve the trade war.

One potential legal path would involve creation of an open, plurilateral agreement. ${ }^{53}$ China itself would likely be the largest economic beneficiary to its own subsidies reform. ${ }^{54}$ Nevertheless, much thought is still required to make the solution-and complementary package of what else to include-something that would be politically and economically palatable to all parties.

\footnotetext{
${ }^{52}$ For a broader discussion, see Chad P. Bown, Self-Enforcing Trade: Developing Countries and WTO Dispute Settlement (Ch. 8), Washington: Brookings Institution Press (2009).

${ }^{53}$ See Bernard Hoekman and Petros C. M avroidis, 'Embracing Diversity: Plurilateral Agreements and the Trading System', 14 World Trade Review (2015): 101-16; Rudolf Adlung and Hamid Hamdou, 'Plurilateral Trade Agreements: An Escape Route for the WTO?' 52 Journal of World Trade (2018): 85-111; and Richard E. Baldwin and Philip Thornton, M ultilateralising Regionalism: Ideas for a WTO Action Plan on Regionalism, London: CEPR Press (2008).

${ }^{54}$ See Lardy (2019, fn. 12).
} 
Figure 1. US steel, aluminum and solar panel imports covered by antidumping, countervailing duties and safeguards, 1995-2017
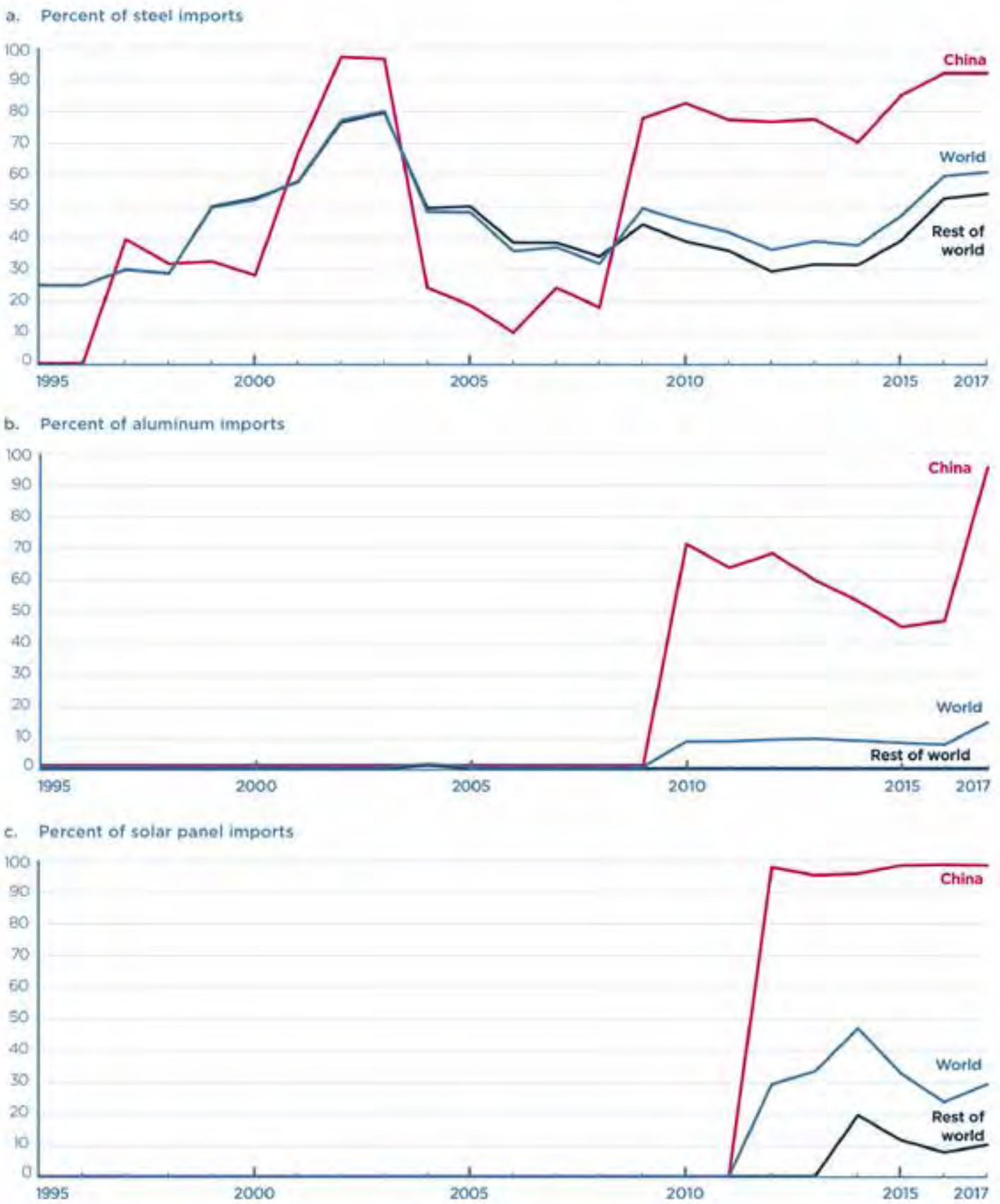

Note: Share of US import of steel (panel a), aluminum (panel b), and solar panels (panel c) covered by antidumping, countervailing duties, or safeguards in effect each year.

Source: Bown (2018, fn. 17) and authors' calculations. 
Figure 2. US total imports from China covered by antidumping and countervailing duties, 1980- 2018

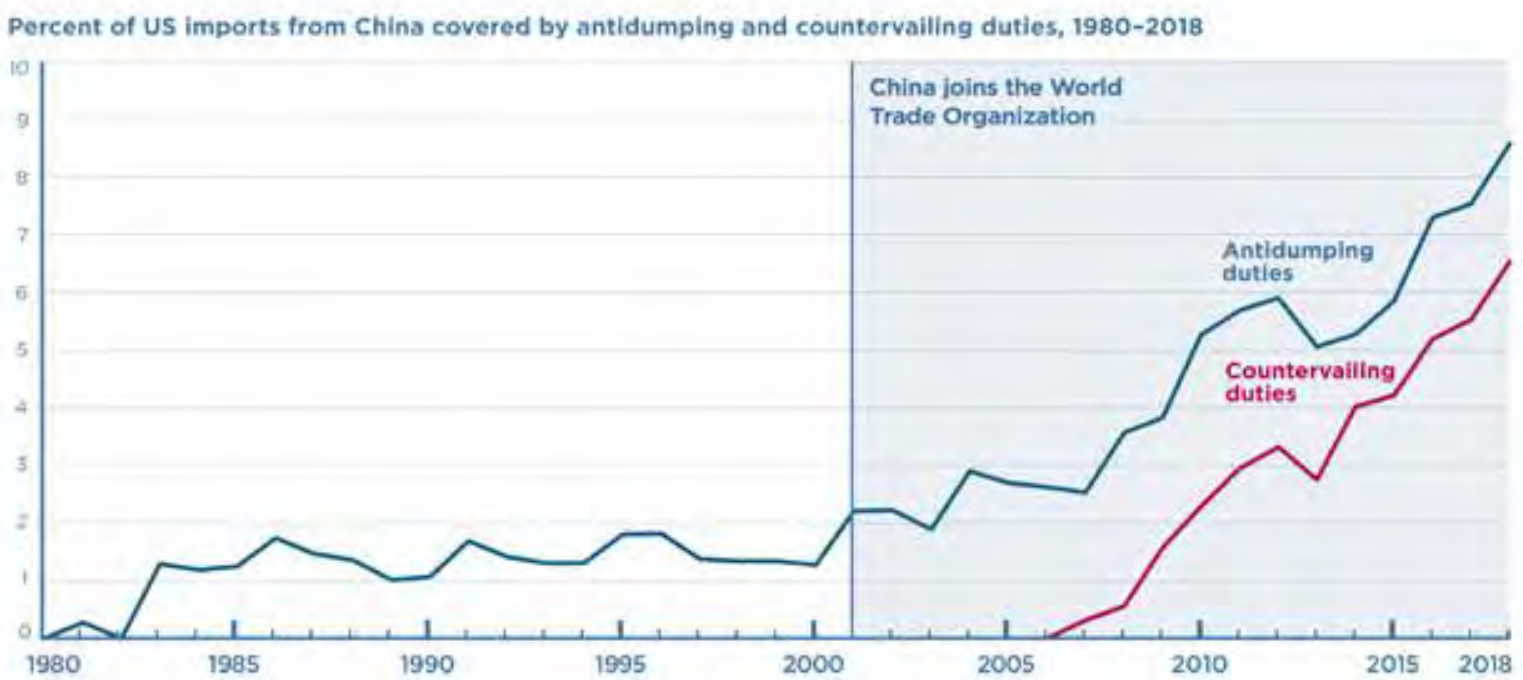

Note: Share of US total goods imports from China covered by antidumping or countervailing duties in effect each year.

Source: Bown (2019, fn. 3). 